\title{
The Role of Paclobutrazol on Production Strategy of Curcuma alismatifolia Gagnep. for Off-Season Marketing
}

\author{
Kriangsuk Boontiang*, Prasit Chutichudet and Benjawan Chutichudet \\ Department of Agricultural Technology, Faculty of Technology, Mahasarakham University, \\ Mahasarakham 44150, Thailand
}

(*Corresponding author's e-mail: kriangsuk.b@msu.ac.th)

Received: 5 May 2020, Revised: 16 April 2021, Accepted: 5 May 2021

\begin{abstract}
From September 2017 through February 2018, this open field research was conducted with 6 random treatments and 10 replications. Plants grown under sunlight source with paclobutrazol (PBZ) treatments were compared to those grown under sunlight plus $2 \mathrm{~h}$ night break (without PBZ) (control 1) and those grown under sunlight source (without PBZ) (control 2). The results showed that PBZ treatments lowered both height and peduncle length substantially. In comparison to control 1, the $600 \mathrm{mg} / \mathrm{L} \mathrm{PBZ}$ treatment led in non-significant changes in physical growth and anthocyanin content in coma bract and fertile bract. Plants grown under sunshine $+2 \mathrm{~h}$ night break without PBZ had the shortest number of days to inflorescence appearance (day 46) and first flower opening (day 72). Plants cultivated under control 2 conditions had the largest delay in inflorescence emergence (day 61) and first flower opening (day 92). These findings will aid in the low-cost cultivation of $C$. alismatifolia cultivated in the open field during the off-season.
\end{abstract}

Keywords: Curcuma alismatifolia Gagnep., Low-cost strategy, Off-season marketing, Open field cultivation, Paclobutrazol

\section{Introduction}

Thailand is a major producer of flowers and other ornamental crops in the tropical climatic zone [1,2], with the Aalsmeer Flower Auction in the Netherlands [3] ranking Thailand ninth in market share. Thai floriculture's production area was projected to be 3,100 hectares in 2014, with an export value of $\$ 38.1$ million US dollars. The market value in 2014 was $13.7 \%$ significantly higher than previously reported [4]. Curcuma alismatifolia Gagnep. called "Patumma" or "Siam Tulip" is one of the most popular varieties of flowers exported from Thailand. Its market value was ranked $2^{\text {nd }}$ after orchids [5]. The 3 main market demands are that this plant can be used as cut flowers, potted plants, and its rhizomes can be grown for landscape gardening [6]. The normal season for cultivation of this plant involves initial growth in the early rainy season with its inflorescence occurring through the rainy season (June-August). Total non-structural carbohydrate (TNC) from green leaves, pseudo-stem, and inflorescence in the upper part of the plant is translocated down to the rhizome which remains dormant throughout the long period of winter until summer (September-April). Therefore, off-season production of C. alismatifolia is required due to the market demand for year-round flowers. A technique for breaking dormancy of the rhizome was reported [7], with a night break treatment to improve photosynthesis in C. alismatifolia grown off-season under the greenhouse [8]. However, construction of greenhouses and installation of electrical illumination systems for a night break treatment to cultivate off-season flowering of $C$. alismatifolia is cost burdens to the farmers. A low-cost productive technique for off-season cultivation of C. alismatifolia in the open field demonstrated that physical growth and development of plants grown under sunlight with paclobutrazol (PBZ) were comparable to those were grown under sunlight plus $2 \mathrm{~h}$ night break without PBZ [9]. Therefore, they were significantly different compared to those grown under sunlight source only.

In light of the aforementioned considerations, the goal of this study was to assess the impact of PBZ on $C$. alismatifolia's off-season production strategy in order to satisfy the high occasional demand of flower markets. 


\section{Materials and methods}

\section{Plant materials}

Rhizomes of $C$. alismatifolia Gagnep. cv. Kimono Pink (potted cultivar) were selected for offseason cultivation. Preparation of plant materials was performed following a described method [9]. Rhizomes used in this work were $1.5-1.7 \mathrm{~cm}$ in diameter with 4 storage roots. All selected rhizomes were stored under ambient conditions at $15{ }^{\circ} \mathrm{C}$ and relative humidity $(\mathrm{RH})$ at $70 \%$ for 4 months to delay the germination activity. Immediately after storage, the rhizomes were soaked in tap water for 3 days (daily water changes) and were placed in a planting bed, filled with sand and rich husk ash at a ratio of 1:1 to stimulate germination. Germinating rhizomes were transplanted ( 1 rhizome per 1 pot) into $6 \times 11$ inches of plastic bags filled with soil, sand, and rich husk ash at a ratio of 1:1:1. Off-season cultivation of C. alismatifolia was carried out in the open field from September 2017 to February 2018 at a research station in the Department of Agricultural Technology, Faculty of Technology, Mahasarakham University, Thailand.

\section{Experimental design}

A completely randomized design was arranged in 6 treatments and 10 replications (10 plants/ replication) as follows:

Treatment 1. Plants were grown under natural sunlight with a $2 \mathrm{~h}$ night break (11:00 pm-01:00 am) without PBZ (control 1). The electrical illumination system was providing supplementary light from 100 $\mathrm{W}$ incandescent lamps. Each lamp was set up at $1.5 \mathrm{~m}$ height above the ground (4 lamps per square meter). Extra light treatment was continuously used from week 3 after transplanting until true flowers were in full bloom.

Treatment 2. Plants were grown under sunlight sources without PBZ (control 2).

Treatment 3. Plants were grown under sunlight sources with $200 \mathrm{~mL} / \mathrm{L} 15 \% \mathrm{PBZ}(\mathrm{w} / \mathrm{v}$ in tap water) application.

Treatment 4. Plants were grown under sunlight sources with $400 \mathrm{~mL} / \mathrm{L} 15 \% \mathrm{PBZ}$ application.

Treatment 5. Plants were grown under sunlight sources with $600 \mathrm{~mL} / \mathrm{L} 15 \% \mathrm{PBZ}$ application.

Treatment 6. Plants were grown under sunlight sources with $800 \mathrm{~mL} / \mathrm{L} 15 \%$ PBZ application.

A single application of $200 \mathrm{~mL}$ of different concentrations of PBZ $(0,200,400,600$ and $800 \mathrm{~mL} / \mathrm{L})$ was poured into planting media at week 3 after transplanting.

\section{Determination of vegetative growth and physical development}

The following data were recorded at weeks 6,8 and 10 after transplanting; shoot length, number of new shoots, leaf number per plant, total leaf area (measured using a CI-203 Handheld Leaf Area Meter), date of inflorescence appearance, date of true flower blooming, peduncle length, inflorescence length, inflorescence diameter, number of fertile bracts, and number of coma bracts.

\section{Determination of biochemical substances}

The following data were recorded on day 90 after transplanting:

1. Chlorophyll content in the leaf: Liquid chlorophyll from a fresh leaf was extracted with $50 \%$ ethanol. The absorption at 665 and $625 \mathrm{~nm}$ of purified chlorophyll was determined spectrophotometrically. Chlorophyll content was determined using the chlorophyll index method [10].

2. Total non-structural carbohydrate (TNC) content in rhizome, pseudo-stem, leaf, peduncle, and inflorescence was determined using the method of extraction of total available carbohydrates [11]. A dried sample from each part of the plant material was ground and digested with sulfuric acid $\left(\mathrm{H}_{2} \mathrm{SO}_{4}\right)$. The digested sample was then reacted with Nelson's alkaline copper reagent. In all samples, absorption at 540 $\mathrm{nm}$ was measured spectrophotometrically. TNC content was determined by comparison with a D-glucose standard curve.

3. Total anthocyanin content in coma bract was extracted and measured according to [12,13] and absorption was analyzed spectrophotometrically at 515 and $700 \mathrm{~nm}$. Total anthocyanin content was determined comparing to total monomeric anthocyanin pigment.

\section{Statistical analysis}

Data were statistically analyzed using the Statistics Computer Program, version 8. Analysis of variance and statistically significant differences were compared using Least-Significant Difference (LSD) $(p \leq 0.05)$. 


\section{Results and discussions}

For C. alismatifolia grown under sunlight source with 200, 400, 600 and $800 \mathrm{~mL} / \mathrm{L} \mathrm{PBZ} \mathrm{treatments,}$ there were no significant differences in plant height at week 6 after transplanting. Their shoot lengths were significantly different compared to controls 1 and 2 (Table 1). At weeks 8 and 10, there were no significant differences in the heights of plants grown under sunlight source with 600 and $800 \mathrm{~mL} / \mathrm{L} \mathrm{PBZ}$ treatments. The highest plants (26.57 and $28.89 \mathrm{~cm}$ above the surface of planting media) at weeks 8 and 10 were grown under sunlight source plus $2 \mathrm{~h}$ night break treatment, without PBZ. There were no significant differences in the number of new shoots and number of leaves. Although there were no significant differences in the total area of leaf compared to the control 1 in plants grown under sunlight source with 400 and $600 \mathrm{~mL} / \mathrm{L} \mathrm{PBZ}$ treatment at weeks 6, 8 and 10; there were significant differences compared to other treatments.

For plants grown under control 1, there were significant differences in physical development. Significant differences occurred in the earliest flowering parameters, date of inflorescence appearance and date of true flower blooming (day 46 and 72 after transplanting). Inflorescence appearance in plants grown under sunlight source with 400, 600 and $800 \mathrm{~mL} / \mathrm{L} \mathrm{PBZ}$ treatment occurred on the same date as day 54 after transplant. The longest delay in the date of inflorescence appearance and true flower blooming was found in plants grown under control 2. Non-significant differences occurred in the length of peduncle in plants grown under sunlight source with 400 and $600 \mathrm{~mL} / \mathrm{L} \mathrm{PBZ}$. Therefore, the length of peduncle found in both treatments was shorter than in controls 1 and 2 but was longer than plants grown under sunlight source with $800 \mathrm{~mL} / \mathrm{L}$ PBZ. Inflorescence size on plants grown as control 1 was significantly different in its length and diameter $(14.32$ and $7.62 \mathrm{~cm})$ as well as numbers of fertile bracts and coma bracts (10.50 and 8.57 bracts), compared to other treatments. The minimal size of inflorescence was found on plants grown under control 2 conditions (Table 2).

Maximum chlorophyll content in leaves was found in plants grown under control 1 conditions (68.34 mg. $\mathrm{g}^{-1}$ dry weight). This result had no significant difference compared to the chlorophyll content in leaves found in those plants grown under sunlight source with $600 \mathrm{~mL} / \mathrm{L}$ PBZ treatment $\left(67.92 \mathrm{mg} . \mathrm{g}^{-1}\right.$ dry weight). A significant difference in TNC content in the rhizome, pseudo-stem, peduncle, and inflorescence occurred in plants grown in control 1 as well as in plants grown under sunlight source with $600 \mathrm{~mL} / \mathrm{L}$ PBZ. However, this result was significantly different compared to other treatments (Table 3).

Table 1 Roles of PBZ on vegetative growth of C. alismatifolia Gagnep. cv. Kimono Pink grown offseason.

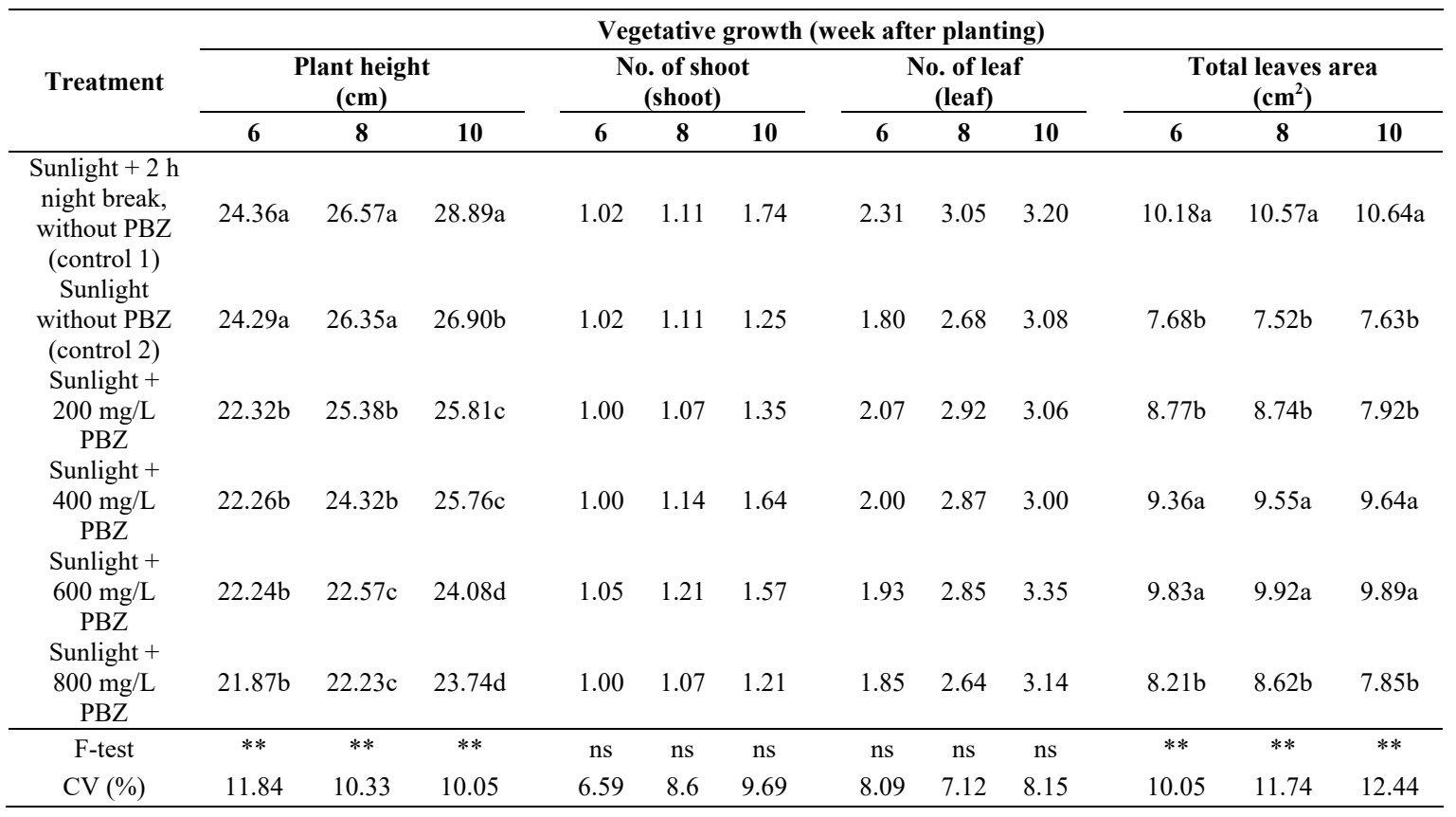

$\mathrm{ns}=$ non-significant difference, $* *$ significant difference

Mean values in the same column with different letters were significantly different $(p \leq 0.05)$ 
Table 2 Roles of PBZ on inflorescence qualities of C. alismatifolia Gagnep. cv. Kimono Pink grown offseason.

\begin{tabular}{|c|c|c|c|c|c|c|c|}
\hline \multirow[b]{2}{*}{ Treatment } & \multicolumn{7}{|c|}{ Inflorescence qualities } \\
\hline & $\begin{array}{c}\text { Day to } \\
\text { inflorescence } \\
\text { appearance } \\
\text { (day) }\end{array}$ & $\begin{array}{c}\text { Day to } \\
\text { flower } \\
\text { blooming } \\
\text { (day) }\end{array}$ & $\begin{array}{l}\text { Length of } \\
\text { peduncle } \\
\quad(\mathrm{cm})\end{array}$ & $\begin{array}{c}\text { Length of } \\
\text { inflorescence } \\
\text { (cm) }\end{array}$ & $\begin{array}{c}\text { Inflorescence } \\
\text { diameter } \\
\text { (cm) }\end{array}$ & $\begin{array}{l}\text { No. of fertile } \\
\text { bract (bract) }\end{array}$ & $\begin{array}{l}\text { No. of coma } \\
\text { bract (bract) }\end{array}$ \\
\hline $\begin{array}{c}\text { Sunlight }+2 \text { h night break, without } \\
\text { PBZ (control 1) }\end{array}$ & $46 \mathrm{~d}$ & $72 d$ & $25.49 \mathrm{a}$ & $14.32 \mathrm{a}$ & $7.62 \mathrm{a}$ & $10.50 \mathrm{a}$ & $8.57 \mathrm{a}$ \\
\hline Sunlight without PBZ (control 2) & $61 \mathrm{a}$ & $92 \mathrm{a}$ & $24.95 \mathrm{a}$ & $13.96 \mathrm{~b}$ & $4.83 b$ & $8.34 \mathrm{~b}$ & $6.73 b$ \\
\hline Sunlight $+200 \mathrm{mg} / \mathrm{L} \mathrm{PBZ}$ & $58 b$ & $88 b$ & $23.82 \mathrm{ab}$ & $13.66 \mathrm{~b}$ & $5.96 \mathrm{ab}$ & $9.81 \mathrm{a}$ & $8.21 \mathrm{a}$ \\
\hline Sunlight $+400 \mathrm{mg} / \mathrm{L} \mathrm{PBZ}$ & $54 \mathrm{c}$ & $84 \mathrm{c}$ & $22.67 b$ & $13.41 \mathrm{~b}$ & $6.34 \mathrm{a}$ & $10.07 \mathrm{a}$ & $8.07 \mathrm{a}$ \\
\hline Sunlight $+600 \mathrm{mg} / \mathrm{L} \mathrm{PBZ}$ & $54 \mathrm{c}$ & $83 c$ & $21.95 b$ & $13.22 b$ & $7.52 \mathrm{a}$ & $10.27 \mathrm{a}$ & $8.50 \mathrm{a}$ \\
\hline Sunlight $+800 \mathrm{mg} / \mathrm{L} \mathrm{PBZ}$ & $54 \mathrm{c}$ & $82 c$ & $19.34 \mathrm{c}$ & $11.07 \mathrm{c}$ & $7.20 \mathrm{a}$ & $10.64 \mathrm{a}$ & $8.43 \mathrm{a}$ \\
\hline F-test & $* *$ & $* *$ & $* *$ & $* *$ & $* *$ & $* *$ & $* *$ \\
\hline $\mathrm{CV}(\%)$ & 8.72 & 9.87 & 10.83 & 8.46 & 10.02 & 11.84 & 9.14 \\
\hline
\end{tabular}

$\mathrm{ns}=$ non-significant difference, $* *$ significant difference

Mean values in the same column with different letters were significantly different $(p \leq 0.05)$

Table 3 Roles of PBZ on biochemical substances in plant component of C. alismatifolia Gagnep. cv. Kimono Pink grown off-season.

\begin{tabular}{|c|c|c|c|c|c|c|c|}
\hline \multirow[b]{2}{*}{ Treatment } & \multirow{2}{*}{$\begin{array}{c}\text { Chlorophyll } \\
\text { Content in leaf } \\
\left(\mathrm{mg} \cdot \mathrm{g}^{-1} \text { dry weight) }\right.\end{array}$} & \multicolumn{5}{|c|}{ Total nonstructural carbohydrate content $\left(\mathrm{mg}^{-g^{-1}}\right.$ dry weight) } & \multirow{2}{*}{$\begin{array}{c}\text { Anthocyanin content } \\
\text { in coma bract } \\
\text { (mg/100 } \mathrm{g} \text { fresh weight) }\end{array}$} \\
\hline & & Rhizome & Pseudo-stem & Leaf & Peduncle & Inflorescence & \\
\hline $\begin{array}{c}\text { Sunlight }+2 \text { h night break, } \\
\text { without PBZ (control 1) }\end{array}$ & $68.34 \mathrm{a}$ & $43.45 \mathrm{a}$ & $42.36 \mathrm{a}$ & 10.89 & $20.28 \mathrm{a}$ & $20.39 \mathrm{a}$ & $15.80 \mathrm{a}$ \\
\hline $\begin{array}{c}\text { Sunlight without PBZ } \\
\text { (control 2) }\end{array}$ & $63.51 \mathrm{c}$ & $38.29 \mathrm{c}$ & $38.61 \mathrm{c}$ & 10.06 & $16.95 \mathrm{c}$ & $16.44 \mathrm{c}$ & $12.23 \mathrm{c}$ \\
\hline Sunlight $+200 \mathrm{mg} / \mathrm{L} \mathrm{PBZ}$ & $64.28 \mathrm{c}$ & $40.25 b$ & $40.10 \mathrm{~b}$ & 10.27 & $17.82 b$ & $18.00 \mathrm{~b}$ & $12.35 b$ \\
\hline Sunlight $+400 \mathrm{mg} / \mathrm{L} \mathrm{PBZ}$ & $66.36 \mathrm{~b}$ & $41.12 b$ & $41.84 \mathrm{ab}$ & 10.38 & $18.18 b$ & $18.41 b$ & $13.08 \mathrm{~b}$ \\
\hline Sunlight $+600 \mathrm{mg} / \mathrm{L} \mathrm{PBZ}$ & $67.92 \mathrm{a}$ & $42.58 \mathrm{ab}$ & $42.29 \mathrm{a}$ & 10.64 & $20.16 \mathrm{a}$ & $20.25 \mathrm{a}$ & $14.77 \mathrm{a}$ \\
\hline Sunlight $+800 \mathrm{mg} / \mathrm{L} \mathrm{PBZ}$ & $66.03 \mathrm{~b}$ & $41.05 \mathrm{~b}$ & $42.13 \mathrm{a}$ & 10.21 & $18.32 b$ & $18.34 \mathrm{~b}$ & $13.65 \mathrm{~b}$ \\
\hline F-test & $* *$ & $* *$ & $* *$ & ns & $* *$ & $* *$ & $* *$ \\
\hline $\mathrm{CV}(\%)$ & 8.5 & 4.7 & 6.3 & 10.2 & 7.6 & 6.8 & 8.7 \\
\hline
\end{tabular}

$\mathrm{ns}=$ non-significant difference, $* *$ significant difference

Mean values in the same column with different letters were significantly different $(p \leq 0.05)$

Off-season production of floricultural crops is an alternative approach to meeting high demand and high market value. This strategy leads to higher earnings, which affects the farmers' profits and lessens the risk of significant losses. This study evaluated the roles of PBZ on quantitative growth and quality yield of $C$. alismatifolia in an open field experiment as a strategy for off-season cultivation. An off-season planting date was chosen in early December to promote plant growth and yield, and to meet a high season demand of flowers or for occasional celebration of valentine's greeting in February. The effects of PBZ on the growth and development of $C$. alismatifolia were evaluated by comparing plants grown under sunlight plus $2 \mathrm{~h}$ night break to support good quality of inflorescence in off-season planting [14] without PBZ (methodology that incurs the greatest cost to farmers), and plants grown under sunlight source without PBZ (regular cultivation). The results indicated that there were significant differences in plant height and the length of peduncle in controls 1 and 2 compared to PBZ treatments. The new shoot, number of leaves, total area, and chlorophyll content in leaves of plants grown under sunlight source with $600 \mathrm{~mL} / \mathrm{L}$ PBZ treatment were not significantly different compared to plants grown under control 1. Therefore, those results were significantly different compared to other treatments. Our results agreed with the finding that in field-cultivated Helianthus annuus L. [15] and Dendranthema $\mathrm{x}$ grandiflora cv. Lilian Hoek [16], the effects of higher concentrations of PBZ include reduction in plant height and root length. On the other hand, our results showed that proper concentration of PBZ application can increase the chlorophyll content in leaves, compared to untreated plants. Higher chlorophyll content was partly due to an additional layer of palisade mesophyll $[17,18]$. Total chlorophyll content in green leaves shown in plants grown under sunlight source with $600 \mathrm{~mL} / \mathrm{L}$ PBZ treatment was reflecting sufficient 
photosynthesis [19-21]. Additionally, plants grown under sunlight source with $600 \mathrm{~mL} / \mathrm{L} \mathrm{PBZ} \mathrm{treatment}$ showed no significant differences in TNC content in the rhizome, pseudo-stem, peduncle, and inflorescence, or of anthocyanin content in the coma bract, compared to control 1. However, there were significant differences compared to plants grown in control 2.

The flowering parameters: Number of dates of inflorescence appearance and first flower blooming in plants grown in sunlight source with PBZ treatment were delayed by 1 week compared to the plants grown in control 1. Therefore, the same parameters recorded in plants grown in sunlight source with PBZ treatment occurred 1 week earlier than those plants grown in control 2 (Table 2). Additionally, the vegetative growth and inflorescence qualities of plants grown in this study were comparable to the response of PBZ treatment for off-season cultivation [9], in which the planting date was set in late September to produce inflorescences during the high season and for occasional celebrations such as Christmas and New Year in late December to early January. Our results indicated that PBZ is a novel plant growth regulator acting as a stress protectant in C. alismatifolia Gagnep. grown under differential ambient conditions in the winter through early summer [22-26]. The present findings will be beneficial to the low-cost production strategy of $C$. alismatifolia for the off-season to meet the high occasional demand of flower markets.

\section{Conclusions}

PBZ application is recommended for strategic planning of low-cost cultivation of C. alismatifolia Gagnep. grown off-season in the open field to meet high market demand for high-value year-round flowers, without the construction of protected conditions or installation of electrical illumination systems for a night break treatment. A concentration of $600 \mathrm{~mL} / \mathrm{L} \mathrm{PBZ}$ treatment can be used to induce chlorophyll pigment, TNC accumulation, and anthocyanin content in coma bract in C. alismatifolia Gagnep. grown off-season.

\section{Acknowledgements}

The authors are very grateful for the assistance of the Department of Agricultural Technology, Faculty of Technology, Mahasarakham University, Thailand.

\section{References}

[1] S Wannakrairoj. Status of ornamental plants in Thailand. Acta Hortic. 2005; 788, 29-36.

[2] R Kamenetsky. Development and utilization of ornamental geophytes: Research challenges and sustainable production. Acta Hortic. 2017; 1171, 9-16.

[3] KP Prabhakaran Nair. The Ornamental Curcuma. In: KP Prabhakaran Nair (Ed.). The agronomy and economy of turmeric and ginger. $1^{\text {st }}$ ed. Elsevier, Landon, 2013, p. 205-15.

[4] S Lekawatana and B Suwannamek. Ornamental plant in Thailand. Acta Hortic. 2017; 1167, 11-6.

[5] S Khumkratok, K Boontiang, P Chutichudet and P Pramual. Geographic distributions and ecology of ornamental Curcuma (Zingiberaceae) in northeastern Thailand. Pak. J. Biol. Sci. 2012; 15, 92935 .

[6] WB Miller. Flower bulbs worldwide: Perspectives on the production chain and research. Acta Hortic. 2017; 1171, 1-8.

[7] LA Thohirah, LF Catherine and N Kanalakshi. Breaking bud dormancy and different shad levels for production of pot and cut Curcuma alismatifolia. Am. J. Agr. Biol. Sci. 2010; 5, 385-8.

[8] P Siritrakulsak. 2010, Effects of planting date, night break treatment and fertilizer application on physiological responses of Curcuma alismatifolia Gagnep. Ph.D .Dissertation .Chiang Mai University, Chiang Mai, Thailand.

[9] K Boontiang, B Chutichudet and P Chutichudet. Effect of paclobutrazol on growth and development of Curcuma alismatifolia Gagnep. grown off-season .Naresuan J .Sci. Tech .2019; 27, 1-8.

[10] JH Madison and AH Anderson. A chlorophyll index to measure turf grass response. Agron. J. 1963; 55, 461-4.

[11] D Smith, GM Paulsan and CA Raguse. Extraction of total available carbohydrates from grass and legume tissue. Plant Physiol. 1964; 36, 960-2.

[12] MM Giusti and RE Wrolstad. Anthocyanin, characterization and measurement of anthocyanin by $U V$-visible spectroscopy. In: RE Wrolstad (Ed.). Current protocol in food analytical chemistry. John Wiley \& Sons, New York, 2001, p. 1-13. 
[13] MM Giusti and RE Wrolstad. Characterization and measurement of anthocyanins by UV visible spectroscopy. In: RE Wrolstad and SJ Schwartz (Eds.). Handbook of food analytical chemistry. John Wiley \& Sons, New York, 2005, p. 19-31.

[14] S Ruamrungsri. The physiology of Curcuma alismatifolia Gagnep. as a basis of the improvement of ornamental production. Eur. J. Hortic. Sci. 2015; 80, 316-21.

[15] SD Koutroubas and CA Damalas. Sunflower response to repeated foliar application of paclobutrazol. Planta Daninha 2015; 33, 129-35.

[16] GE Burrow, TS Boag and WP Stewart. Changes in leaf, stem and root anatomy of Chrysanthemum cv. Lillian Hoek following paclobutrazol application. J. Plant Growth Regul. 1992; 11, 189-94.

[17] I Kolodziejek, M Waleza, J Koziol and A Mostowska. Ultrastructure of mesophyll cells and pigment content in senescing leave of maize and barley. J. Plant Growth Regul. 2003; 22, 217-27.

[18] R Bisht, P Singariya, SP Bohra and N Mathur. Triazoles: Their effects on net photosynthetic rate, transpiration rate and stomatal resistance in Setaria italica plants grown in vivo. Asian J. Biol. Sci. 2007; 21, 271-6.

[19] CA Jaleel, P manivannan, B Sankar, A Kishorekuma, S Sankari and R Panneerselvam. Paclobutrazol enhances photosynthesis and ajmalicine production in Catharantus roseus. Process Biochem. 2006; 42, 1556-70.

[20] BR Gadi, V Laxmi and SP Bohra. Note on effect of plant regulators on net photosynthetic rate, transpiration rate and stomatal resistance in ber (Zizyphus mauritiana cv. Seb). Curr. Agr. Res. J. 2001; 25, 143-6.

[21] R Gopi, CA Jaleel, MM Azooz and R Panneerselvam. Photosynthetic alterations in Amorphophalluss cmpanulatus with triazoles drenching. Global J. Mol. Sci. 2009; 4, 15-8.

[22] PR Soumya, P Kumar and M Pal. Paclobutrazol: A novel plant regulator and multi-stress ameliorant. Indian J. Plant Physiol. 2017; 22, 267-78.

[23] J Jungklang and K Saengnil. Effect of paclobutrazol on Patumma cv. Chiang Mai Pink under water stress. Songklanakarin J. Sci. Tech. 2012; 34, 361-6.

[24] JS Kuehney, S Maurico, PP Maria and CB Patrica. Effect of light intensity, photoperiod and plant growth retardants on production of Zingiberaceae as potted plants. Acta Hortic. 2005; 683, 145-154.

[25] J Jungklang, K Saengnil and J Uthaibutra. Effects of water-deficit stress and paclobutrazol on growth, relative water content, electrolyte leakage, proline content and some antioxidant changes in Curcuma alismatifolia Gagnep. cv. Chiang Mai Pink. Saudi. J. Biol. Sci. 2017; 24, 1505-12.

[26] W Tesfahum. A review on: Response of crops to paclobutrazol application. Cogent Food Agr. 2018; 4, 1525169. 